\title{
Di Desa, Rematik Sering Disebut Encok
}

\author{
Slamet Riyadi. \\ Program Studi Pendidikan Dokter, FK, Universitas Sebelas Maret. \\ slametriyadi60@staff.uns.ac.id
}

$\begin{array}{ll}\text { Jenis Artikel } & \text { : Artikel ilmiah populer kesehatan } \\ \text { Media Massa } & : \text { Mingguan Kartika } \\ \text { Tanggal Pemuatan } & : \text { 5 Oktober } 1986\end{array}$

\begin{abstract}
Abstrak
Meskipun istilah rematik telah dikenal oleh masyarakat secara meluas sampai ke desa-desa, namun jika kita ingin mendapatkan kejelasan tentang istilah tersebut, biasanya mulai timbul kebingungan. Hal tersebut wajar, sebab istilah tadi berasal dari luar negeri yang sudah dimasukkan ke dalam bahasa Indonesia. Sedangkan dalam masyarakat kita telah ada suatu istilah yang artinya kurang lebih sama yaitu encok
\end{abstract}

Kata kunci: kesehatan, penyakit, rematik

\section{Pendahuluan}

Menurut dokter Sunarto, pada Kongres Nasional Ikatan Rematologi Indonesia I di Semarang tahun 1983, asal kata rematik dulu dari bahasan Yunani (Grik), yaitu Rheumaticos. Rheum berarti lendir atau cairan yang dikeluarkan, maka dari itu untuk penyakit influenza yang gejalanya demam, batuk, dan linu-linu di seluruh tubuh, dahulu disebut "Epidemic rheuma".

Rematik merupakan istilah yang digunakan untuk menyebut bermacam-macam gangguan dari tubuh yang ditandai oleh radang, perubahan-perubahan karena gangguan pertukaran zat atau kemunduran jaringan tubuh yang terutama mengenai sendi-sendi atau bangunan yang ada hubungannya dengan persendian.

Ciri khas penyakit rematik adalah adanya rasa sakit, kaku yang dapat disertai atau tidak disertai terbatasnya gerakan dari bagian tubuh yang terkena. Dengan semakin 
berkembangnya ilmu pengetahuan, terutama di bidang kedokteran, maka kelompok penyakit rematik berkembang menjadi ilmu pengetahuan tersendiri yang dinamakan: Rematologi.

Dari kelompok penyakit rematik ini terdapat ciri-ciri utama yang sama antara masingmasing jenis, baik berupa keluhan gejalanya, setidak-tidaknya mirip. Keadaan demikianlah yang menyebabkan kesulitan dalam menetapkan termasuk jenis mana penyakit tersebut.

\section{Penyebabnya}

Telah disebutkan di atas, bahwa penyakit rematik merupakan kelompok penyakitpenyakit yang memberikan tanda-tanda yang mirip, sehingga sebagai penyebab penyakit tersebut juga bermacam-macam. Sebagian golongan penyakit telah diketahui penyebabnya, tetapi golongan yang lain hingga kini belum diketahui penyebabnya. Mungkin untuk tahun-tahun mendatang dengan majunya ilmu kedokteran akan dapat diketahui penyebabnya.

Secara garis besar, penyebab rematik dapat dibagi menjadi dua golongan yaitu: karena radang dan bukan radang. Radang adalah gangguan atau penyakit yang ditandai dengan: bengkak, panas, nyeri, merah dan gangguan fungsi. Penyebab tersebut dapat dipersempit menjadi dua, ialah karena infeksi dan bukan infeksi.

Jadi bila rematik tersebut disebabkan oleh radang, maka akan didapati kelima tanda radang di atas dengan jelas. Sedangkan penyebab yang bukan radang misalnya karena gangguan atau ketegangan jiwa. Ketegangan jiwa sering menyebabkan timbulnya bermacam-macam penyakit termasuk rematik. Sebaliknya, penyakit rematik yang menahun sering menimbulkan ketegangan jiwa.

Apakah faktor keturunan juga berpengaruh? Memang ada kecenderungan pada penyakit rematik tertentu yang dapat menurun kepada keturunan penderita, misal anak, cucu, dan sebagainya. Dengan kemajuan teknik pemeriksaan kedokteran, pada benang-benang 
pembawa keturunan si penderita ditemukan sesuatu yang sama dengan anak cucunya, sehingga kemungkinan besar mereka akan menderita penyakit yang serupa dengan penderita (orang tuanya).

\section{Perjalanan Penyakitnya}

Seperti halnya penyakit lain, penyakit rematik ada yang timbul secara mendadak, ada yang timbul secara kumat-kumatan bahkan ada yang menyelinap tapi makin lama makin memberat. Dalam perjalanan penyakit selanjutnya ada yang dapat disembuhkan dengan sempurna tanpa meninggalkan cacat, meski dengan pengobatan sederhana atau bahkan tanpa pengobatan.

Ada pula yang dapat disembuhkan jika pengobatannya tidak terlambat namun ada jenis-jenis penyakit rematik tertentu yang sulit diobati dan bahkan tak dapat disembuhkan dengan tindakan pengobatan, sehingga meninggalkan cacat.

Ada juga penyakit rematik yang nampak adanya penyembuhan pada sendi-sendi yang terkena, tetapi dalam perjalanan penyakitnya masih berlanjut dan menyerang alatalat dalam, misal jantung sehingga dapat menimbulkan kerusakan-kerusakan pada jaringan jantung. Kerusakan pada jantung yang lebih parah dinamakan penyakit jantung rematik.

Keadaan yang dapat menimbulkan penyakit jantung rematik adalah demam rematik. Demam rematik sering menyerang anak-anak atau dewasa muda, dimana keadaan kesehatan lingkungannya jelek. Pada penyakit rematik yang menahun terdapat kecenderungan menyerang jenis kelamin tertentu. Ada yang lebih sering menyerang wanita, sebaliknya ada yang sering menyerang pria. Mengapa demikian? Hal tersebut sampai sekarang sulit diterangkan. 


\section{Timbul Masalahnya}

Tentang timbulnya penyakit rematik pada usia lanjut merupakan hal yang belum dapat dicegah. Hal ini mungkin akibat proses ketuaan atau keausan alat-alat tubuh. Tetapi tidak semua usia lanjut mempunyai keluhan-keluhan rematik, meskipun telah terjadi keausan.

Terutama penyakit rematik yang menahun akan memberikan akibat yang memberatkan bagi penderita maupun keluarganya. Dengan adanya cacat yang timbul, maka mengakibatkan mengurangnya atau tidak mampu bergerak, bekerja maupun melakukan kerja sehari-hari.

Akibat lebih lanjut yang menetap, maka timbul masalah lain, yaitu: Pertama, keluhan si sakit dan keluarganya. Kecemasan akan timbul hingga mengakibatkan ketegangan jiwa bagi penderita maupun keluarganya. Si sakit akan menjadi pasif dan mengasingkan diri karena merasa minder, sedang keluarganya menjadi bingung, ada kalanya merasa malu dengan tetangganya.

Masalah kedua, yaitu dengan adanya cacat dan sering kambuh, maka akan menjadi beban ekonomi, sebab pengeluaran biaya terus-menerus. Dari uraian di atas dapat disimpulkan bahwa rematik (encok) merupakan kelompok penyakit yang mempunya gejala mirip satu dengan yang lainnya. Penyakit tersebut menyerang pada persendian atau alat-alat tubuh yang berhubungan dengan pergerakan. Tidak semua penyakit rematik menyebabkan cacat dan sebagai penyebabnya bermacam-macam.

\section{REFERENCES}

Riyadi, S. (5 Oktober 1986). Di desa, rematik sering disebut encok. Mingguan Kartika. 


